\title{
Trends in Student Radicalization across University Campuses in Afghanistan
}

Robert Zaman

Abdul Ahad Mohammadi
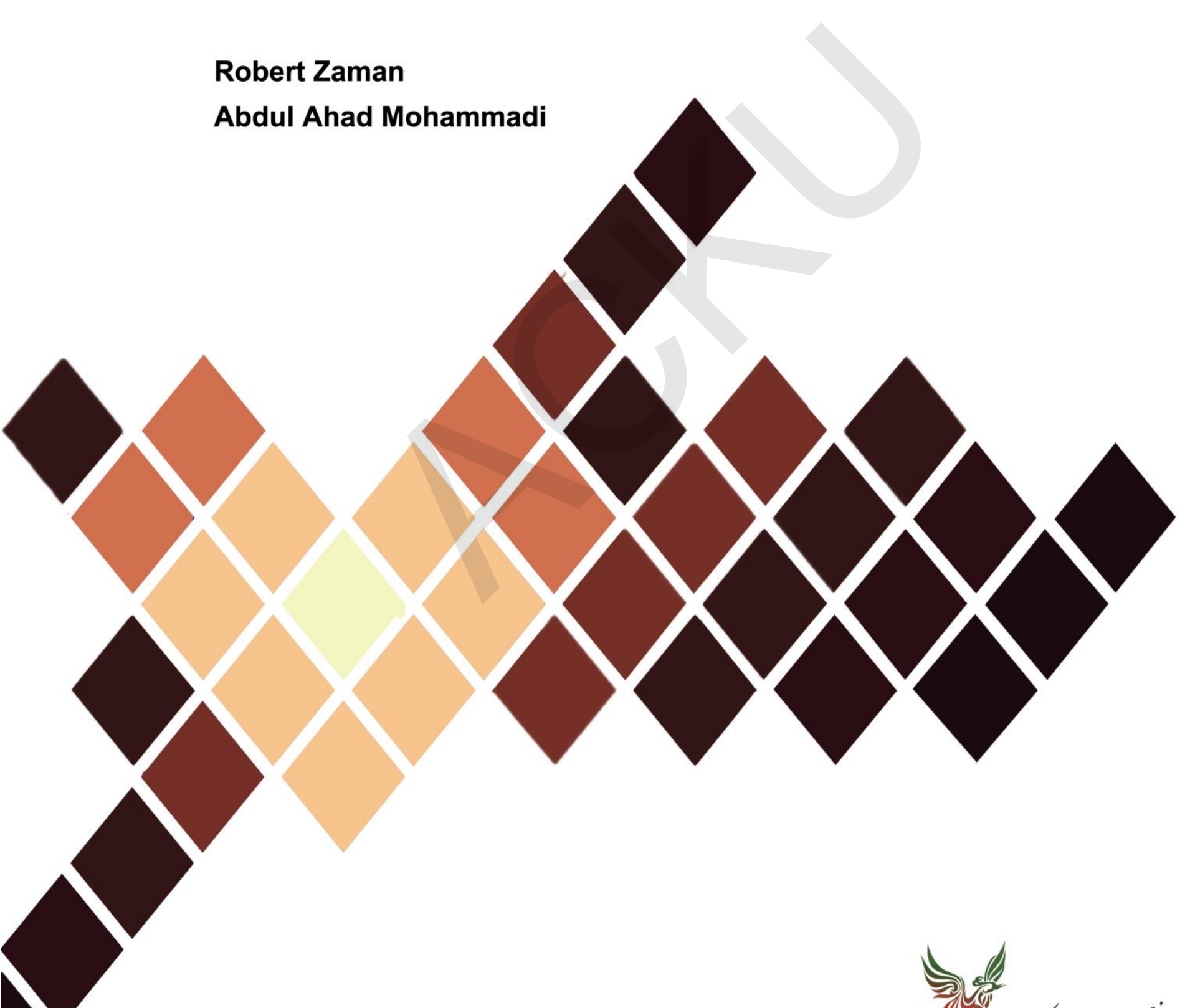

AISS-02-2014

October 2014

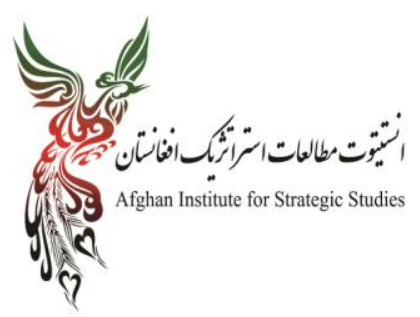


This Page Intentionally Left Blank 


\section{Afghan Institute for Strategic Studies}

\section{Trends in Student Radicalization across University Campuses in Afghanistan}

Authors: Mr. Robert Zaman and Mr. Abdul Ahad Mohammadi

Principal Researchers: Mr. Musab Omer and Mr. Hussain Hasrat

Research Design Review and Peer Review:

- Professor Shahrbanou Tadjbakhsh, Director of the program on Human Security at the Master of Public Affairs (MPA), Institute of Political Studies, Sciences Po, Paris and Associate Researcher, Peace Research Institute of Oslo (PRIO)

- Professor Chandra Lekha Sriram, Professor of International Law and International Relations, University of East London

- Dr. Timor Sharan, Political Economy Consultant, Afghan Parliament, Department for International Development (DFID-Afghanistan)

Field Researchers:

- Mr. Agha Shrin

- Mr. Ahmad Sayede

- Mr. Bashir Ahmad

- Mr. Haseb Husham

- Mr. Khalil Farzam

- Mr. Akbar Khumaini

- Ms. Mahnaz Mawzoon

- Mr. Ali Sajad

- Mr. Sakhi Dad Mahdyar

- Mr. Sayed Ahmad Sadat 
This Page Intentionally Left Blank 


\section{CONTENTS}

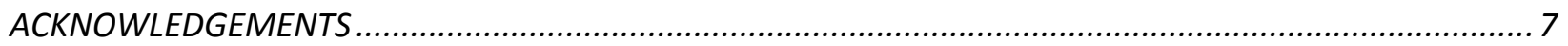

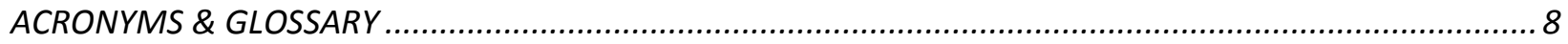

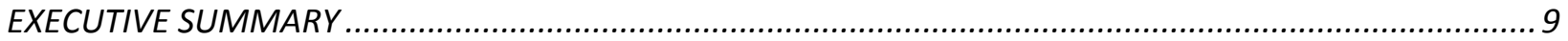

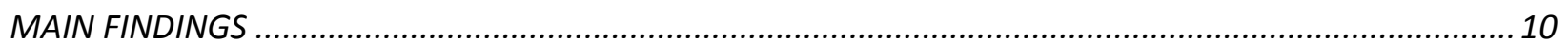

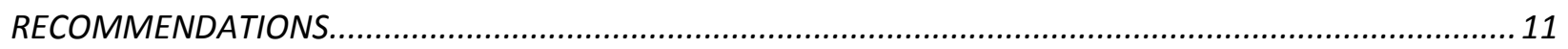

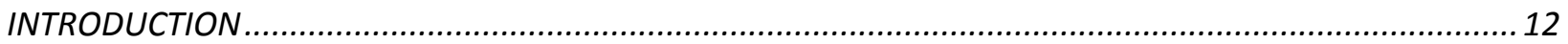

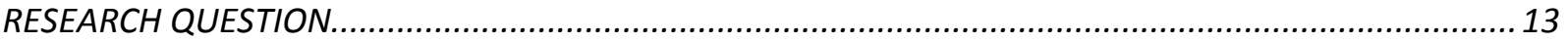

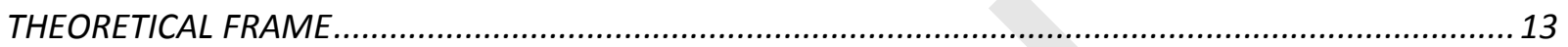

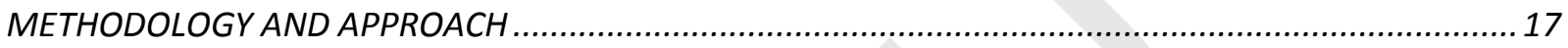

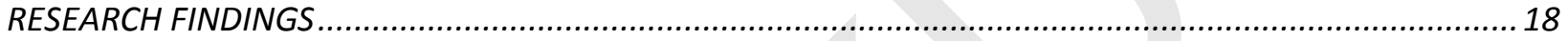

The Characteristics of Student Protest across Afghanistan ............................................................. 19

The Extent of Institutionalized Radicalization on University Campuses ............................................. 23

The Extent of External Influences on the Radicalization of Students .................................................25

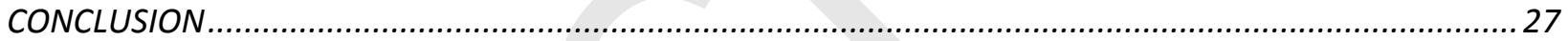

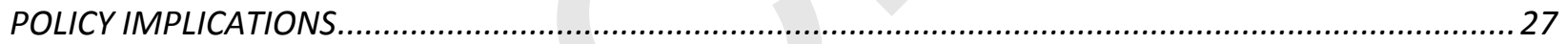

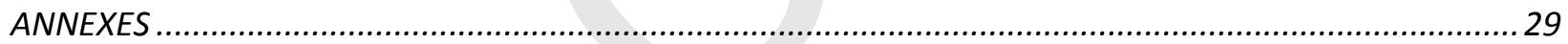

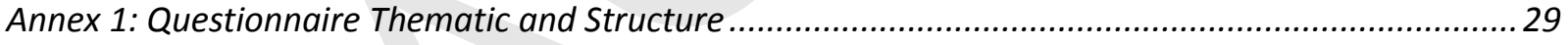

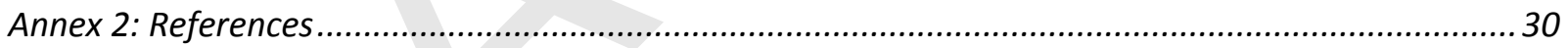

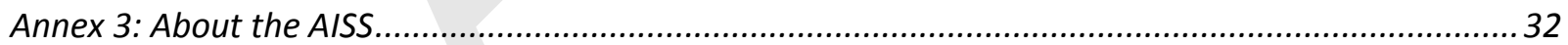

FIGURES

Figure 1: Map of Selected Provinces Covered in this Study ...........................................................................6

Figure 2: Degree of Acceptance of the Norms of Human Rights and Democracy........................................19

Figure 3: Reasons for Afghan Resentment against the US and the West..................................................20

Figure 4: Change in Tolerance toward other Ethnic and Sectarian Groups...............................................22

Figure 5: Opinions on Justification of Taliban Armed Opposition against the Afghan Government............24 
Figure 1: Map of Selected Provinces Covered in this Study

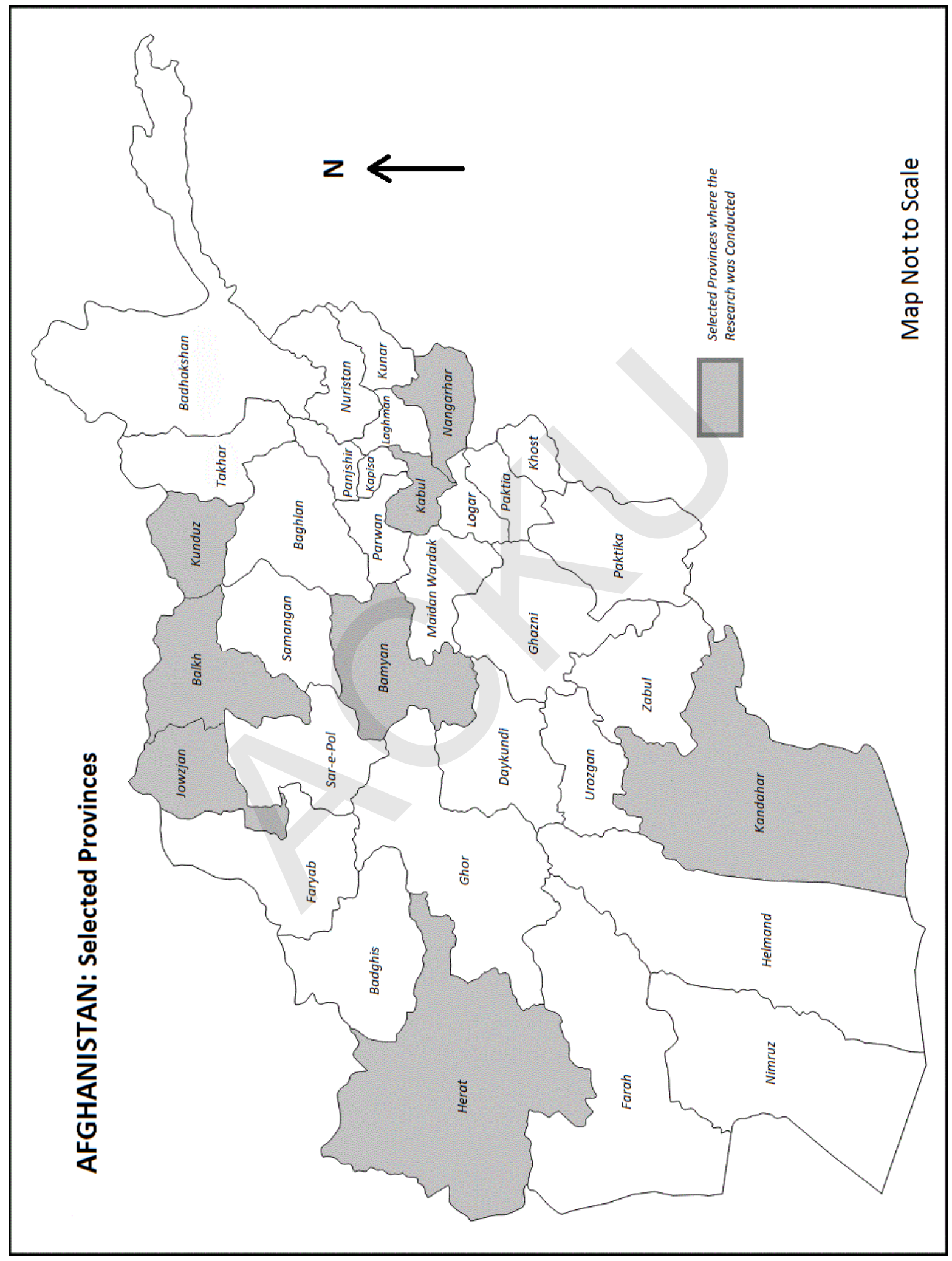




\section{ACKNOWLEDGEMENTS}

The authors are grateful to the Afghan Institute for Strategic Studies (AISS) for its logistical support and to the National Endowment for Democracy (NED) for its generous financial contribution to this project.

We are also very grateful to our peer reviewers, Professor Shahrbanou Tadjbakhsh, Professor Chandra Lekha Sriram, and Dr. Timor Sharan for their thoughtful and expert comments and feedback in the preparation of this study.

Special thanks to all of our field researchers for their tireless contributions in the field: Mr. Agha Shrin, Mr. Ahmad Sayede, Mr. Bashir Ahmad, Mr. Haseb Husham, Mr. Khalil Farzam, Mr. Akbar Khumaini, Ms. Mahnaz Mawzoon, Mr. Ali Sajad, Mr. Sakhi Dad Mahdyar, and Mr. Sayed Ahmad.

Thanks are also due to our principal researchers, Mr. Musab Omer and Mr. Hussain Hasrat for their diligent contribution in the preparation of this report.

Also, we sincerely appreciate the thoughtful contributions of our colleagues at AISS for their involvement in the design and field work management of the study.

Special thanks also to Mr. Abass Farasoo, the Deputy Director General of Regional Cooperation Department (RCD) in the Ministry of Foreign Affairs of Afghanistan (MoFA) and Liaqat ali Amiri also of MoFA, for their feedback and comments in framing the questionnaires for the study. 


\section{ACRONYMS \& GLOSSARY}

$\begin{array}{ll}\text { AREU } & \text { Afghanistan Research and Evaluation Unit } \\ \text { AISS } & \text { Afghan Institute for Strategic Studies } \\ \text { HIA } & \text { Hezb-e-Islami Afghanistan } \\ \text { MoHE } & \text { Afghanistan Ministry of Higher Education } \\ \text { MoFA } & \text { Afghanistan Ministry of Foreign Affairs } \\ \text { NED } & \text { National Endowment for Democracy } \\ \text { ISAF } & \text { International Security Assistance Force } \\ \text { NATO } & \text { North Atlantic Treaty Organization } \\ \text { NDS } & \text { National Directorate of Security }\end{array}$

Imam - is a person entrusted in an Islamic leadership role to both lead prayers in a mosque as well as to participate as a community leader or to give guidance to community leaders.

Madrasa - derived from Arabic, is the term for educational institutions. However, more recent usage associates the term with Islamic religious school.

Shariat - is Islamic canonical law which is based on the Quran but has jurisdiction over both religious and secular duties and prescribes the penalties for offences against such duties.

Jihad - with a literal translation of 'struggle', it is most closely associated with 'holy war', whether a believer's internal struggle with his faith or the struggle to maintain and defend Muslim society and Islam.

Quran - is the holy book revealed to the Prophet Muhammad over twenty-three years by God. It consists of 114 chapters and is written in Arabic.

Saqafat-e-Islami - are compulsory courses of study at Afghan universities in introduction to Islamic culture and values.

Hejab - is a veil that Muslim women use to cover their heads as a sign of modesty, privacy, and morality and in abeyance of Islamic law.

Takfir - is an Arabic word which refers to the practice of excommunication wherein one Muslim declares that another Muslim has abandoned Islam and is no more a part of Muslim society. Wahabism and Salafism are notorious for excommunicating people according to this principle. 


\section{EXECUTIVE SUMMARY}

This study aims to examine the trends in student radicalization across eight university campuses in Afghanistan. We conclude from our survey of student and staff views and an analysis of the character of protests across campuses that the extent of student radicalization varies. In particular, we come to three noteworthy findings. First, most university students are more concerned over prospects of post-graduation follow-on careers than ideological ambition. Second, while we find that most students and lecturers denounce radical views and violence, a relatively more aggressive response to both the policies of the Afghan government and the armed international intervention exhibited by students from universities in Kabul, Qandahar and Nangarhar suggests differentiated patterns across university campuses, with these campuses suggestive of a stronger tendency toward radicalized views. Finally, as an institution, the university does not play a strong role in the radicalization of its students. Rather, a charged political climate and the readily available opportunity to mobilize quickly enable students to stand in protest rather easily. However, findings also suggest that it is this same easy access to mobilize in protest that seems to attract a number of external groups as evident by the black, white and green flags representative of al-Qaeda, the Taliban, and the militant wing of Hezb-eIslami Hekmatyar. Moreover, it is these protests that seem to encourage polarization and consequential division on campus which increasingly resemble the practice of takfir. Referring to the practice of excommunication wherein one Muslim declares that another Muslim has abandoned Islam, takfir is in direct competition with the more tolerant teachings common to the characteristically liberal curriculum of public universities. While protest in and of itself is a characteristic common to progressive democracies, evidence suggests that some student protests do call for division along sectarian lines or the suppression of women's rights, both of which stand in contradiction to democratic principles and pose a threat to stability. With more than sixty-three percent of the Afghan population under the age of twenty-four, left unchecked such influence has the likelihood and potential to expand with substantial consequences for development and security in Afghanistan. As Afghanistan moves into a new phase of its era of state-building, a special focus on meeting the needs of its youth and in particular of Afghan university students is indispensable in meeting and maintaining lasting stability and prosperity.

This study is the first part of an ongoing series of papers dedicated to examining the trends in radicalization across the various sectors throughout Afghanistan. Launched in late 2013, we plan follow-on studies to complement the series, including examinations of the trends in radicalization in madrassas across Afghanistan and within the Afghan security forces. 


\section{MAIN FINDINGS}

1. As an institution, the university does not play a strong role in the radicalization of its students. Rather, a charged political climate and the readily available opportunity to mobilize quickly enable students to stand in protest rather easily. However, such accessibility seems to be attracting a number of external groups as evident by the black, white, and green flags representative of al-Qaeda, the Taliban, and the militant wing of Hezb-e-Islami Hekmatyar.

2. While the character of student response at most universities suggests moderate views, those from Kabul, Qandahar and Nangarhar indicated a relatively stronger sense of radical tone. Whereas much else remains relatively similar across the universities studied, these campuses stand out as the ones where the black, white, and green flags representative of al-Qaeda, the Taliban, and the militant wing of Hezb-e-Islami Hekmatyar are present, suggesting that such external groups are the source of potential radicalization rather than the university.

3. Aside from Bamian University, most lecturers do not keep with the Ministry of Higher Education's recommended syllabus and develop religious studies curriculum syllabus in line with their own ideological interpretations and expectations. As a consequence, the likelihood of such curriculum to stray from moderate to more extreme tone increases.

4. The majority of students and lecturers reject the idea that violence is a means of protest justified by Islam with most student protest characterized by rhetoric against ongoing violence and civilian casualties, and not by religious or cultural difference.

5. Students largely are more concerned about their post-graduation follow-on careers than ideological ambitions as evidenced by their call for better on campus programs and postgraduation follow-on support. 


\section{RECOMMENDATIONS}

1. As a means of limiting and insulating university students from the infiltration of external influences, we recommend a civil society coalition or watchdog organization to monitor higher education practices, standards, and quality of instruction. They should especially watch for external interference in the development of curriculum and the implementation of practices and standards that may promote radical ideology.

2. As a means of countering potentially precarious differences in curriculum and practices across university campuses, the Ministry of Higher Education should institutionalize a national standard across all university campuses and for all faculties. Additionally, the Ministry should provide continuing education for staff and lecturers aimed at promoting and maintaining such national standards.

3. As post-graduation employment is a primary concern of students, the Ministry of Higher Education should institutionalize job placement, internship, and fellowship programs for students and prospective graduates based on merit with particular emphasis on eliminating the favoritism and nepotism that drives students toward radicalized protests.

4. As a means of encouraging greater intergroup participation and a move beyond common ethnic and sectarian divisions, the Ministry of Higher Education should provide funding for and diversify student associations to complement the predominantly religious-based associations that already exist. 


\section{INTRODUCTION}

Popular protest in Afghanistan has its roots in the late 1970s and 1980s when religious groups stood against the competing socialist ideology that culminated in the Soviet invasion. Declaring jihad, many turned to radical interpretations of Islam as a means of resistance. Again following the collapse of the Soviet Union and the subsequent civil war that overwhelmed Afghanistan, the Taliban would turn to radical interpretations of Islam as a means of gaining control and governance over the country. Although in both cases extreme measures were applied, the appeal to the notion of defeating the atheist invaders and calming the violence of civil war attracted favor to the jihadist and Taliban ideology by some of the people. With the fall of the Taliban regime in 2001, a number of factors including the continued US presence in Afghanistan, corruption within the government, and unequal distribution of economic benefits have again provoked some of the population to organize in protest.

A number of incidents on university campuses across Afghanistan over the last five years raise concerns over the potential radicalization of students and the role universities may play in encouraging them. In 2009, more than three thousand students from Nangarhar University stood in protest against US operations in the area. Blocking the Kabul-Jalalabad Highway, students burned the US flag while others carried and placed the remains of civilian casualties in front of the governor's house (Kakar, 2009). Again in 2011, university students engaged in protest; this time against the Loya Jirga's decision to support a strategic partnership with the United States (Xinhua, 2011). In another incident, a student was killed during sectarian motivated violent protest at Kabul University when Shia students attempted to use the dormitory mosque to celebrate Ashura ${ }^{1}$ and were confronted by Sunni students (Ahmed, 2012). In 2012, up to five thousand students and faculty of Kabul University protested against an anti-Islam film ${ }^{2}$ produced abroad. Then again, in May 2013, students from Kabul University protested in response to legislation criminalizing violence against women (Hodge \& Totakhil, 2013). Especially troubling is the presence of the black, white (Osman, 2012), and green flags representative of alQaeda, the Taliban, and the militant wing of Hezb-e-Islami Hekmatyar that are flown by small pockets of student protesters at a number of these gatherings. Reportedly, protests are increasingly organized by such fringe political parties and radical activists (Coll, 2012).

\footnotetext{
${ }^{1}$ The celebration of Ashura is observed by Shia and is the commemoration of the martyrdom of the Prophet Mohammad's grandson Husayn ibn Ali who stood in protest against Yazid Sufyan's claim to the Caliphate. Disagreement by followers of Islam as to who should have been the rightful Caliphate resulted in the division founded the Shia and Sunni sect of Islam.

2 The film Innocence of Muslims is a 13-minute low-budget movie posted on YouTube by Egyptian-American Nakoula Basseley Nakoula in 2012 which was met with protest in Australia, Pakistan, Afghanistan, and a number of other places. 


\section{RESEARCH QUESTION}

This study aims to 1) examine the trends in student radicalization on university campuses in Afghanistan; 2) compare the character of student protests across university campuses; and 3) determine where and how universities may limit and insulate campuses against the potential of student radicalization.

\section{THEORETICAL FRAME}

University life is expected to provide students the opportunity to develop the critical thinking skills necessary to intelligently speak their minds. It is a place where students become exposed to varying interpretations of reality as advanced by lecturers and debated among peers. It is where students develop their opinions and find a forum readily available to debate such opinions. However, although student debate remains a valued component of university life which is largely met with approval, history has shown how such peaceful discussions can swiftly transform into activism before intensifying into radicalism (White, 1989; Seferiades \& Johnston, 2012; Frey \& Morris, 1991). Such was the case for Afghanistan where many of the Afghan mujahedeen who fought the Soviets had their beginnings as student activists in the 1970s, including infamous figures such as Gulbuddin Hekmatyar (Hodge \& Totakhil, 2013). It was also on these very same campuses that the competing ideology of communism took hold of another group of students. The actions and discourse of both groups reinforced the polarity that came to define and differentiate them (Emadi, 2001; Kakar, 1995). The rhetoric not only characterized communists as infidels, in a similar tone it identified any supposed Muslims who agreed with any of its tenets as kafirs, or unbelievers. As a result divisions also grew from within the ranks of Muslims (Huldt \& Jansson, 1988; Rubin, 2002), suggestive of extremist sentiments characteristic of radicalism. For this study, we first draw the distinction between academic debate, activism, and radicalism. Second, we develop the concept of radicalization through a survey of existing literature. Finally, we explain the concept of takfir as a tool for operationalizing the concept of radicalization.

A common practice across university campuses, debate is a means of empowering students to use the capacity of language to negotiate and shape impressions of the world (Mitchell, 1998). It is credited with building confidence, public speaking skills, and leadership qualities. Some argue that it is a founding principle and core obligation of universities to develop critical minds capable of engaging in debate (Freeley, 2013; Lapakko, 2009). However, historically the hierarchical system and pedagogical methods that existed within the classrooms of Afghanistan provided teachers with unchallenged authority that often suppressed the exercise of such freedom of speech.

Activism on the other hand, situated between academic debate and radicalism, is characterized by scholars as a social movement (Sampson, 1967; Weiss, Aspinall, \& Thompson, 2012). 
Unlike the individualism of debate, activism draws on a collective of shared opinions while organizing and framing support in symbolism, discourse, and practice (Wiktorowicz, 2004) such as the flags, billboards and rhetoric evident at some gatherings. Its strength, resting on the reciprocal acknowledgement of fellow activists, encourages both new and long time members to 'buy into' and remain committed to the system (Azzi, Chryssochooc, Klandermans, Simon, \& Stekelenburg, 2011). As a result, the perseverance of movements rests on an inner cohesion of its members. It was such conditions that helped to inspire and motivate student activism in the United States during the 1960s (Altbach \& Cohen, 1990) when University of California students protesting for their freedom of speech, staged a sit-in around a police car attempting to transport a fellow activist to prison. Similarly, it was with such sense of community that the prodemocracy protest in Beijing's Tiananmen Square occurred in 1989 despite the risk of violent opposition against protestors (Davis \& Vogel, 1990). One of the earliest signs of campus activism in Afghanistan traces back to the 1960s when increasing numbers of university graduates shared a common frustration over the difficulty in finding employment commensurate to their education level (Gritzner \& Shroder, 2007). Frustration over the under utilization of their skills, and overall anger at the nepotism practiced by the ruling elite, fueled retaliation in the form of public disobedience that consequently led to the crisis and regime change in 1973 (Giustozzi, 2010). History suggests that it was within this context that Afghan Islamic political parties, and more importantly their radical wings, took the opportunity to become more visible. The Soviet invasion that followed only served to further embolden and radicalize these movements, often with the encouragement and support of members the international community (Goodson, 2001; Arnold, 1985; Amstutz, 1986).

Since the events of 9/11, the concept of radicalization has increasingly become elusive ${ }^{3}$. Shrouded in prejudices and preconceptions, interpretations of the concept now lie somewhere between stereotyping and broad assumptions. Being Muslim increasingly has become associated with being radical (Azzi et al., 2011). Consistency in defining radicalization became questionable, leading some to believe that we should "abandon the attempt to use 'radicalization' as an absolute concept" (Sedgwick, 2010). Agreeing with this recommendation, we aim to investigate the relative nature of radicalization across university campuses, and not under absolute terms. Broadly defined, radicalization is a dynamic process whereby an individual or group increasingly relies on violent or near violent means to achieve political, religious, or social ideals and goals (McCauley \& Moskalenko, 2008). However, some argue that violence is not a necessary attribute of radicalization, while others argue that the techniques employed by such groups are violent by their very nature (Ashour, 2009). According to (Springer, Regens \& Edger, 2009), radicalization can begin either as a grassroots bottom-up approach wherein individualized sentiments manifest into radicalized views and approaches, or a top-down

\footnotetext{
${ }^{3}$ As depicted in the chart, media use of the term remained relatively flat until the mid 2000s when there was a proliferation of news reports covering events around 9/11 and the search for Bin Laden and his al-Qaeda operatives. News reports between 2005 and 2007 are characterized by a significant increase and more ambiguous use of the concept (Sedgwick, 2010).
} 
dynamic influence where radical groups recruit and indoctrinate candidates. In both cases, (Silber \& Bhatt, 2007) argue this transition occurs over four phases including pre-radicalization, self-identification, indoctrination, and jihadization, while Azzi et al. (2011) theorize a staircase metaphor to explain the successive psychological transformation and consequential radicalization of individuals and groups. It is exactly such measurable stages of radicalization that could provide early indications of the direction and progress of student protests.

Violent extremism is an exemplary form of radicalism whereby individuals stray further off the path of activism and employ terrorism as a tool to achieving their ideals and goals. Radicalized violent extremism "refers to the processes by which people come to adopt beliefs that not only justify violence but compel it" (Moussalli, 2009). Moreover, according to Wiktorowicz (2005) there has been an "erosion of critical constraints used to limit warfare and violence in classical Islam" (2). Recalling the contributions of religious scholars such as Sayyid Qutb, Mawlana Abul A'la Mawdudi, Taqi al-Din Ibn Taymiyya, Ibn Nuhaas al-Demyati, and Muhammad bin Abdul Wahhab, he argues that such erosion of the mechanisms of constraints allows for a wider definition of apostasy which consequentially divides society and subjects a larger population to violence. Historically Islamic scholars defined apostates as those who leave the faith and declare themselves non-Muslims or those who reject the key tenets of Islam. However, modern day radicals often argue that anyone who does not conform to their individualized and particular interpretation of Islam is an apostate. Moreover, they call for and believe it to be a divine duty to wage jihad against anyone who fails to surrender to their interpretation. Take for example the generally accepted Islamic principle that civilians should not be targeted in war. According to the radical beliefs of al-Qaeda, all civilians living in a Western democracy are subject to attack in accordance with its doctrine of proportional response, which requires an equivalent of Western casualties to that of Muslim casualties of the Iraq and Afghanistan wars (SRS Report for Congress, 2007, p 6). However, violent extremism is not "synonymous with Islamic radicalism...religious belief is only one example of legitimizing ideology that can contribute to violent activity" (Southers, 2013). As a result, grievances over political and social conditions including corruption and personal freedoms could trigger violent extremism as well. For this reason, while ideological radicalization may lead to violence and terrorism, we must accept that violence may occur in the absence of religious radicalization.

This study understands radicalization as an extreme form of protest which is socially constructed and reinforced by student experience with nepotism, ethnic and sectarian discrimination, and differentiated political opinion. According to this interpretation, radicalization remains in a near continuous state, with each event reconditioning and reinforcing student behavior with each passing year, from freshman to job-seeking graduate. As a consequence, one would expect to find increasing levels of radicalization over time as the pressures of competition increases. However, while differences in belief and practices in and of themselves do not constitute radicalization, it is the use of such differences as devices for segregation, alienation, and potential violence that qualifies as radicalization. The practice of takfir, wherein one Muslim 
declares that another Muslim has abandoned Islam, falls sharply on the extreme end of the spectrum as it calls for violent differentiation and division. It is this concept which we use to organize and measure our indicators of radicalization against.

The Kharijites, a movement dating back to the caliphate of Uthman, is said to have advanced the practice of takfir in response to the alleged unjust policies of the third caliph, including nepotism and the unequal distribution of wealth (Timani, 2008). In response, the Kharijites developed a most "rigid and narrow hermeneutic" and encouraged a "wholesale declaration of takfir against diligently observant Muslims who violated even minor aspects" of their interpretation of Islam (Hussain, 2002, p. 2). More importantly, seeking refuge from political manipulation they turned to an "artificial purity through hermeneutics that revolved around an uncompromising doctrine of takfir" which permitted them unchallenged authority to eliminate whomever they considered insufficiently pure (Hussain, 2002). This was not the only case of employing takfir as a political tool. According to (Abu Khalil, 1994), takfir was used as a weapon employed to discredit political opponents while (Moussalli, 2009) argues that the Saudi royal family called on takfir as a means of purification of the population and justification for enforcing the people's loyalties to the King's absolute power. Within the Kharijite movement, the Azariqah, an Islamic sub-sect in the city of Basra called upon similar processes when they labeled all other Muslims unbelievers to justify the killings that followed (Fishbein, 1992). More recently and as a means of permitting jihad against both Muslims and non-Muslims alike, some groups call upon takfir as a means for qualifying their jihad against individuals or groups they understand as non-believers. For example, the 1960s Egyptian radical Islamist movement Al-Takfir Wal-Hijra, aiming to rid the world of 'heretics,' considered much of the Muslim world outside their strict Salafi interpretation of Islam as unbelievers under takfir. Relative to the moderate Islam practiced by vast numbers of Muslims, Wahabism promotes the practice of takfir as a guiding principle and as a result is considered a radical form of Islam by some (Moussalli, 2009). Ironically ordained as a reform movement, Wahabism aimed to return to traditional Islamic values with bans on visiting shrines, the drawing and photographing of humans, and listening to certain types of music, and strict adherence to Islamic over secular jurisprudence. The Islamic State in Iraq and Syria (ISIS) is the most recent materialization of takfiri militancy and radicalization. 


\section{METHODOLOGY AND APPROACH}

For this study, 400 students $^{4}$ were randomly selected by systematic sampling from across eight university campuses throughout Afghanistan. Additionally, focus groups comprised of 15 students each were held on the selected campuses. As this was a random selection, we assume that participants are representative of the ethnic and sectarian make up of the larger provincial community. Moreover, as ethnicity plays a key organizing role in Afghan society, effort was made in finding a diverse selection for the sample. For example, while Kabul University is represented by a fairly ethnically diverse student body, Nangarhar and Qandahar are overwhelmingly Pashtun. In order to offset this imbalance, Herat and Badakhshan were selected because of their majority Tajik makeup. In addition to the student body, two professors of general studies, two faculty members of Islamic theology, and one preacher from university mosques were selected from each campus with the exception of Qandahar where the faculty refused to participate. Secondary source data was collected through a set of interviews with university hostel managers, student union representatives, social scientists, and political analysts.

In addition to basic statistical analysis of our findings, the core of our analysis is qualitative in nature. Examining the statements of interviewees, we determine if and to what extent they experience or advance an 'us versus them' attitude characteristic of the practice of takfir and suggestive of divisive radical ideology. In particular, questions about domestic politics, campus life and values, and expectations for the future were designed to measure responses on a scale ranging from tolerant to hostile. Evidence suggesting tolerance indicated less likelihood of radicalization while indications otherwise suggested the practice of takfir and the potential for radicalization. All answers were codified to discover and check patterns against the study's main themes. We also used concept mapping methodology during qualitative analysis of the data.

The field research team comprised of ten degree holders in the social and behavioral sciences, including journalism, political science, and conflict studies. Each participated in a three-day group training which included an introduction to the study, field research methodology, and techniques for interviewing and administering focus groups. Special emphasis was placed on performing a rigorously uniformed study, which included regular interval quality assurance checks of infield practice and post interview transcriptions.

The field research team did meet with some obstacles and limitations. Although field researchers followed strict ethical guidelines ${ }^{5}$ and presented the appropriate disclosures, including those outlining the confidentiality of identity and testimony, some interviewees were not convinced and remained unaccommodating. Field researchers faced resistance or even outright denial of access in some cases as a result of candidate interviewees' sensitivity to the

\footnotetext{
${ }^{4} 50$ students were selected from each university campus.

${ }^{5}$ Training and approach to fieldwork adhered to standards outlined in the Economic and Social Research Council Ethics (ESRC) Guidelines (See http://www.esrc.ac.uk/about-esrc/information/research-ethics.aspx).
} 
nature of the topic. Some candidate interviewees, attempting to stay within the margins of what they consider the socially acceptable, avoided controversial answers and only conveyed politically correct comments. Similarly, some teachers also refrained from participation for fear of reprisal from the university administration for any critical comments they make. In one instance, the Chancellor of Badakhshan University threatened to call on the National Directorate of Security (NDS) if field researchers did not leave the campus. Security also remained a concern and major obstacle, especially when traveling to Qandahar and Nangarhar.

In addition to finding themselves in conflict conditions, field researchers also had difficulty maintaining contact with interviewees on a number of occasions when security conditions worsened, forcing interviewees to cancel their meetings. Finally, there were a limited number of female participants as a consequence of the problems described above, in particular at universities in Qandahar and Nangarhar. As a result, findings are disproportionately reflective of the opinions of the male population. While we expect that the sample size and corroboration of evidence with those who did participate is sufficient to normalize responses and provide a good approximation of opinions, we also acknowledge the limits of our findings. However, similar future studies aimed at tracking such trends may improve on such limitations.

\section{RESEARCH FINDINGS}

There are three noteworthy findings from our study. First, most university students are concerned over prospects of post-graduation follow-on careers rather than ideological ambition. It is these same students that favor internationally accepted democratic values and human rights. Nonetheless, it is also these same students that protest for a reduction of US operations in Afghanistan and the consequential civilian casualties. Second, while we find that most students and lecturers denounce radical views and violence, a relatively more aggressive response to both the policies of the Afghan government and the armed international intervention exhibited by students and staff from universities in Kabul, Qandahar and Nangarhar suggests differentiated patterns across university campuses, with these campuses reflecting of a stronger tendency toward radicalization. Finally as an institution, the university does not play a strong role in the radicalization of its students, rather external groups take advantage of student mobilization as a means for spreading group propaganda and consequently contribute to student radicalization. 


\section{The Characteristics of Student Protest across Afghanistan}

In Afghanistan, most university students are concerned over prospects of post-graduation followon careers rather than ideological ambition. Similar to the historically secular characteristic of student protests over political and economic concerns (Shafiq, Mason, Seybolt, \& DeLuca, 2014 ; Wasserstrom, 1991), antiwar sentiments (McCormick, 2000; Garfinkle, 1995; Cookson, 1982), and rights and freedoms (Mason, 2000; Wright, 2001), student protests in Afghanistan have been largely characterized by calls for action against discrimination on campus and for better student services (Sultani, 2013), protest against civilian casualties caused by the ongoing insurgency operations led by US forces (Walizada, 2009), and the eradication of corruption and nepotism (Wadsam, 2013). Although students may call on religion to support their arguments during protests, the character and motives behind some protests suggest they place similar emphasis on secular instruments.

Figure 2: Degree of Acceptance of the Norms of Human Rights and Democracy

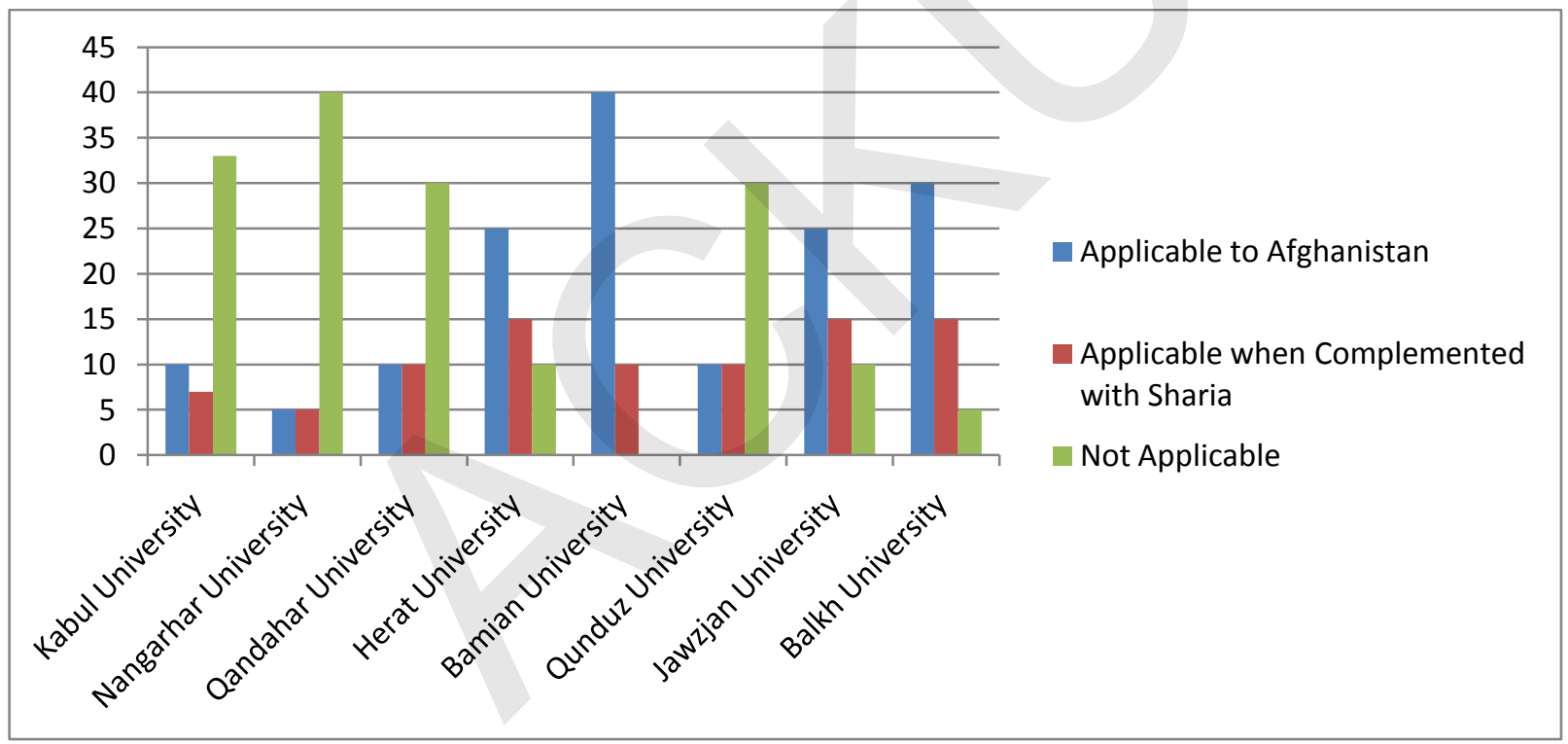

Figure 2 reflects the degree of acceptance of internationally accepted norms of human rights and democracy as measured on a three tier scale from 1) fully applicable to Afghanistan, 2) applicable as a complement to Sharia, and 3) not applicable to Afghanistan as determined by interviewee answers to the question, "are internationally accepted norms of human rights and democracy applicable to Afghanistan?"

Of those interviewed, approximately $75 \%$ of students favor democratic values and norms, while the remaining twenty-five percent largely from Kabul, Qandahar, Nangarhar and Qunduz find that a political system more deeply rooted in Islam is necessary. Favoring the application of such internationally accepted norms, students from Bamian University claim that although "we may accept human rights and democracy... and appreciate that decisions are left for the people to make under such governance...the problem begins with how it is interpreted throughout Afghanistan." Those that disagreed with the applicability of such norms, such as students from Nangarhar University, tend to argue that it has "spoiled family values... and legitimized the 
sexual freedom of women" to perverse ends. Another student from Jalalabad University claimed that the consequences of such freedoms indicate how Democracy is "a culture of infidels." Those students positioned somewhere in the middle, such as one student from Bamian University who argues for international norms as a complement for Sharia, emphasize that although he "respects Democracy and human rights, his respect is limited to the point at which it becomes evident that accepting such norms become harmful to our tradition or religious values."

Although students from Kabul, Qandahar, Nangarhar and Qunduz exhibit a stronger sense of opposition toward the increased institutionalization of democratic norms and practices, they remain diagnostic as they weigh the pros and cons. Similarly, students who argued in favor for such democratic norms and practices also remained critical.

Figure 3: Reasons for Afghan Resentment against the US and the West

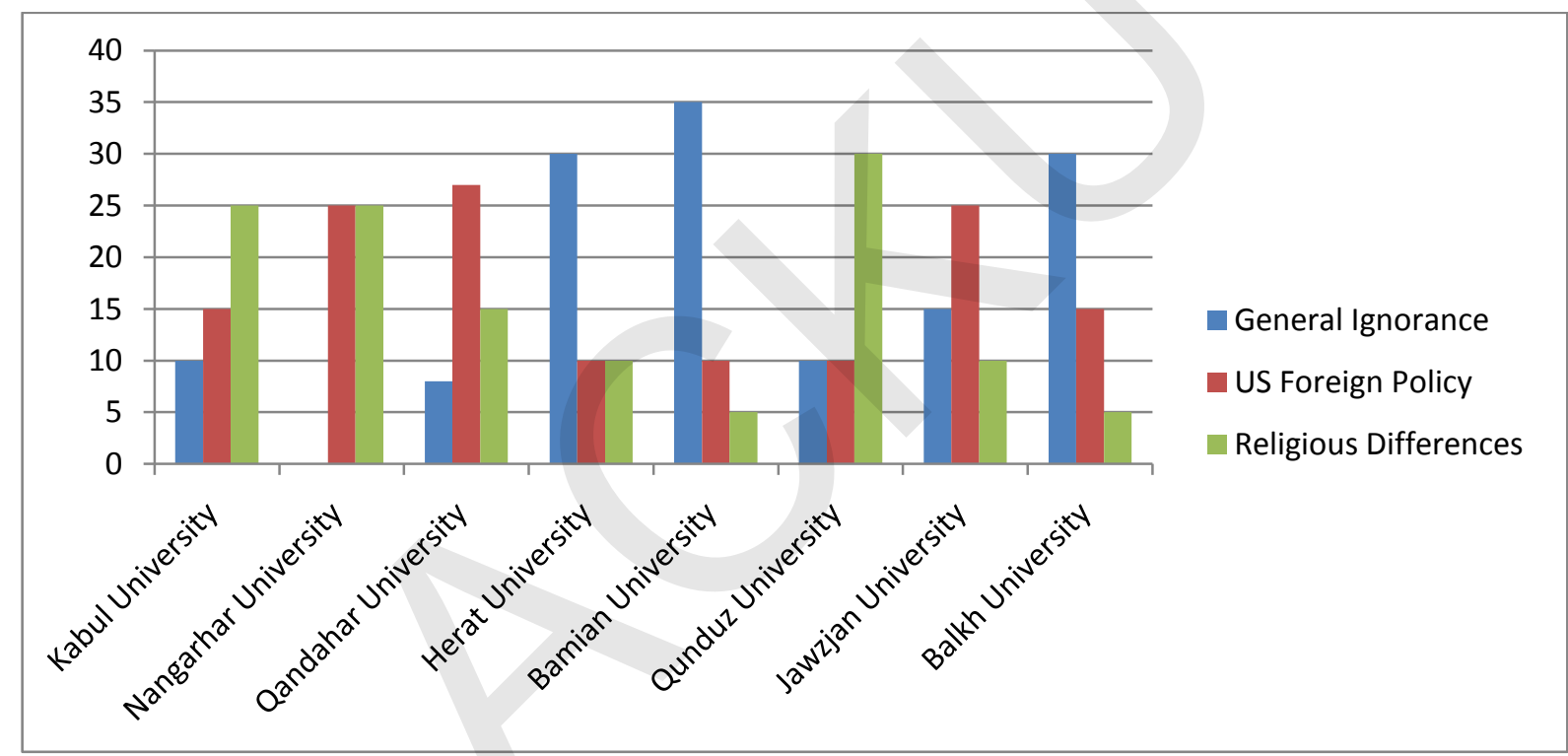

Figure 3 reflects the difference of opinions across university campuses about the reason for resentment against the US and the West, where resentment exists. Answers to the question, "what is the main reason for Afghan resentment against the US and the West?" are organized as 1) general ignorance by the populace about the role of the US and West in Afghanistan, 2) US foreign policy, and 3) Religious differences between Afghanistan and the US and the West.

Of those students that believe the main reason for resentment against the US and the West is chiefly an argument against its foreign policy, many point to the rise of the Taliban as a consequence of US foreign policy in the 1980s. Students from Bamian University claim that it was one of the US's "dirtiest foreign policy" and that the US does not necessarily prioritize the building of unity among the Afghan people. Some students at Herat University went as far as to claim that "like the Soviet Union, the US wants to occupy Afghanistan...and benefit from its natural resources."

In Qandahar where nearly 30\% of students protest against military search operations of local homes, increasingly they hold the US responsible for the corruption and criminal activities in the 
country. These same students believe that self-interests and an aim to destroy the social fabric of Afghan society remains the reason behind the prolonged US presence in Afghanistan. They point to civilian casualties and claim that such senseless deaths are the main reason for their anger and resentment. Similarly sentiments were felt at Jalalabad University where students largely agreed that the deaths of innocent civilians contribute largely to their resentment.

On the other hand, more than $70 \%$ of the students from Bamian University are optimistic about the continued US presence in Afghanistan and believe that it is crucial for maintaining a lasting peace and stability. They largely believe that general ignorance among the people and their tendency to trust the rhetoric of neighboring states, especially Iran and Pakistan, manipulate their opinion and position against a continued US presence in Afghanistan. They further argue that in spite of US attempts to develop a united Afghanistan, the population continues to be fragmented and polarized because of such ignorance and trust in the rhetoric of neighboring states.

Of those students that believe religious differences account for the resentment against the US and the West, many view the diffusion of Western culture and norms as a threat to the historical culture and religion of Afghanistan. According to one student from Balkh University, "Western countries want to weaken our religious values and traditions, hence our resentment," while another student from Herat University points to the Quran and argues that according to the script, Jews and Christians will "never become your friend and to not expect friendship from them." At Qandahar University, students sum up their resentment arguing that the West neither understand nor try to comprehend social and religious differences as they "go about and check women in the streets." 
Figure 4: Change in Tolerance toward other Ethnic and Sectarian Groups

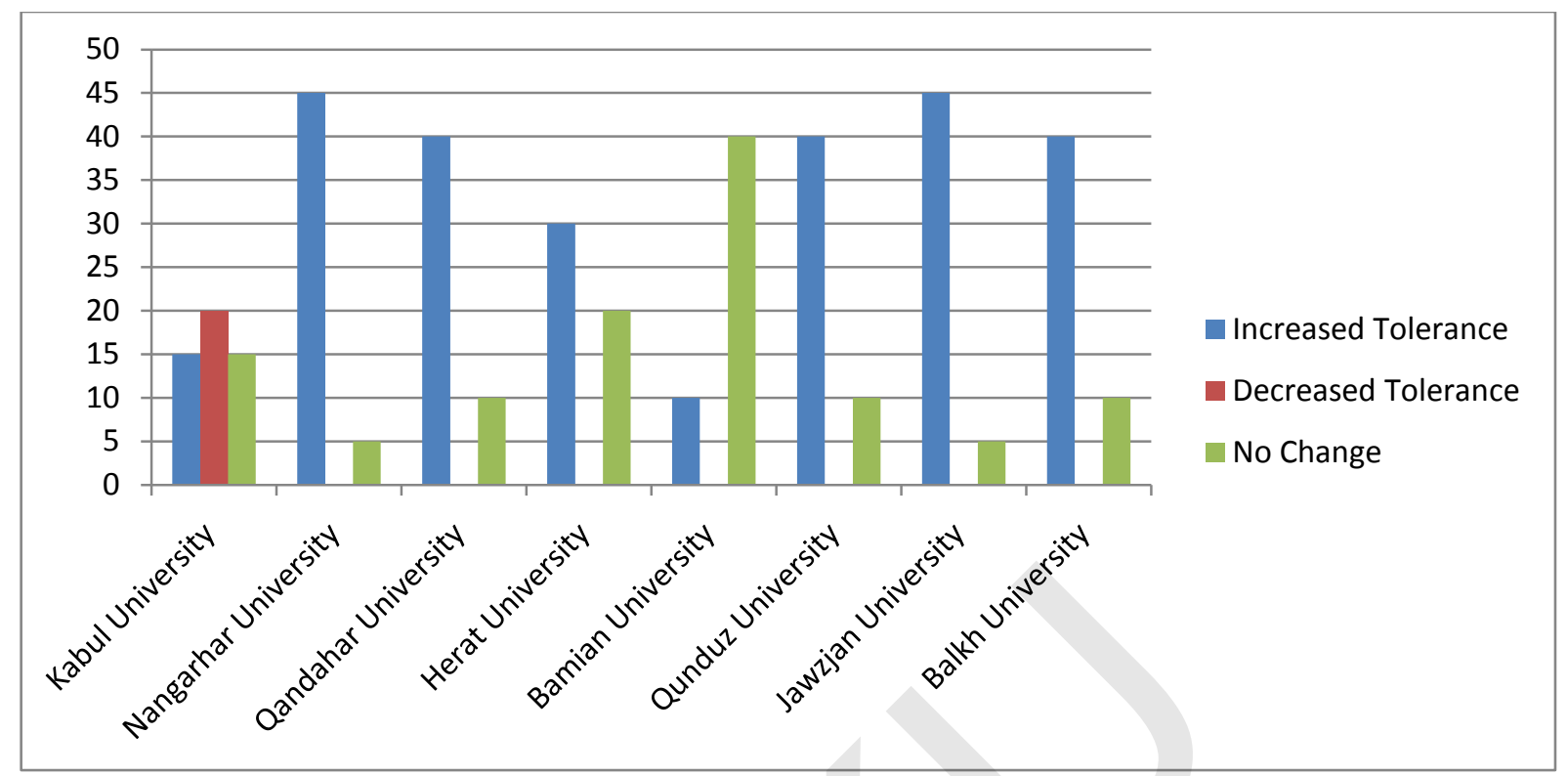

Figure 4 reflects student opinions of how their perception of other ethnic and sectarian groups has changed since they entered university. Student answers to the question "has university life encouraged an increase, decrease or no change in your tolerance toward other ethnic and sectarian groups?" are organized as they have experienced 1) an increase, 2) a decrease, or 3) no change in their perception of other ethnic and sectarian groups since entering university.

When asked about life on campus, most students believe that the diversity found on campus has allowed them to move beyond previously held beliefs and discrimination against other groups. They find a new tolerance encouraged by their bonds as academic peers. Students at Kabul University claim that mixed dormitories, where up to six students from various ethnic and sectarian backgrounds live together, has been a positive learning experience. A student from Bamian University claims that negative views gained throughout his childhood were shattered now that he is on campus and interact daily with students of other ethnicities and sects. However, such sentiments are contradicted in environments where students feel threatened by favoritism toward particular groups, such as in Kabul where such feelings exploded in violence. Students from Kabul argue that when such "fighting and conflict among students from different sects arise, my opinion changes...violence between Hazaras and Sunnis in the dormitory has changed the opinions of many students." Most students agree that corruption, especially in the form of nepotism, fosters a climate of discrimination that results in such unfair treatment that subsequently calls them to protest. Of those students that claim no change in their feeling toward other ethnic or sectarian groups, they largely come from diverse backgrounds where such diverse conditions already existed.

As post-graduation follow-on careers remain a primary concern among students, the rhetoric that underscores their protest largely reflects such aspirations. For example, in calling for better student services and the eradication of corruption, especially those associated with nepotism, students aim to pave a smoother road for their transition to the job market. Also both the 22 
overwhelming support of democratic values and opinions in favor of the US presence in Afghanistan rest on student confidence that such conditions will increase the likelihood of postgraduation opportunities.

Examining the responses of students and the history of protests across university campuses, it becomes evident that factors other than the university account for the differences in student radicalization. Kabul, Nangarhar, and Qandahar have experienced much greater levels of violence compared to Herat, Bamian, Qunduz, Jawzjan and Balkh. As a result, one would expect a stronger sense of opposition and protest against the continued US presence in Afghanistan and the policies of the Afghan government. However other protests, such as those that stand in opposition to the institution of the women's right decree, are also very strong in these same areas suggesting that the area maintains relatively strong conservative and potentially radical beliefs. In combination these two facts suggest that the violence to preserve such values and more importantly the mobilizing of students to violence as a means of preserving such values has its origins off campus. More specifically when tracing student motivation, in the cases where the university fails to meet the expectations of students there is a tendency for them to look for support elsewhere. This phenomenon is particularly striking when student interests match the interests of external groups' protests, consequently developing into a convenient alliance of interests. Arguably, it is such relations of convenience that draws the characteristically moderate tone of student protest to new heights of aggression and radical rhetoric.

\section{The Extent of Institutionalized Radicalization on University Campuses}

The university as an institution does not play a strong role in encouraging student radicalization. Rather, this study finds that lecturers at most universities attempt to find a balance between religious obligations and the secular nature of general studies while also continuing to encourage gender, ethnic, and religious diversity in all aspects of campus life. Moreover, these same lecturers also increasingly look toward further diversification and innovation through academic exchange and visiting researcher opportunity. However, this does not hold true on all campuses.

When asked if the armed opposition by the Taliban against the Afghan government is justified according to Islam, lecturers from Kabul, Qandahar and Nangarhar argued that Muslims should exhaust every means possible to defend Islam and confront corruption, including taking up arms. Lecturers from Bamian, Herat, Qunduz, Jawzjan, and Balkh were largely against violent opposition, arguing for mediation and peaceful settlement. These same faculties believe Islam promotes peaceful coexistence and peaceful means to conflict resolution. However there was concern in Jawzjan where lecturers believed that influence from non-Islamic states increasingly threatens the development of traditional religious studies. Those in Bamian and Herat respond to such concerns by arguing for the adoption of institutionalized exchange programs between universities and local Madrasass. Even so, a small number of lecturers from Qunduz, Jawzjan and Balkh believed that armed opposition to government corruption was necessary. 


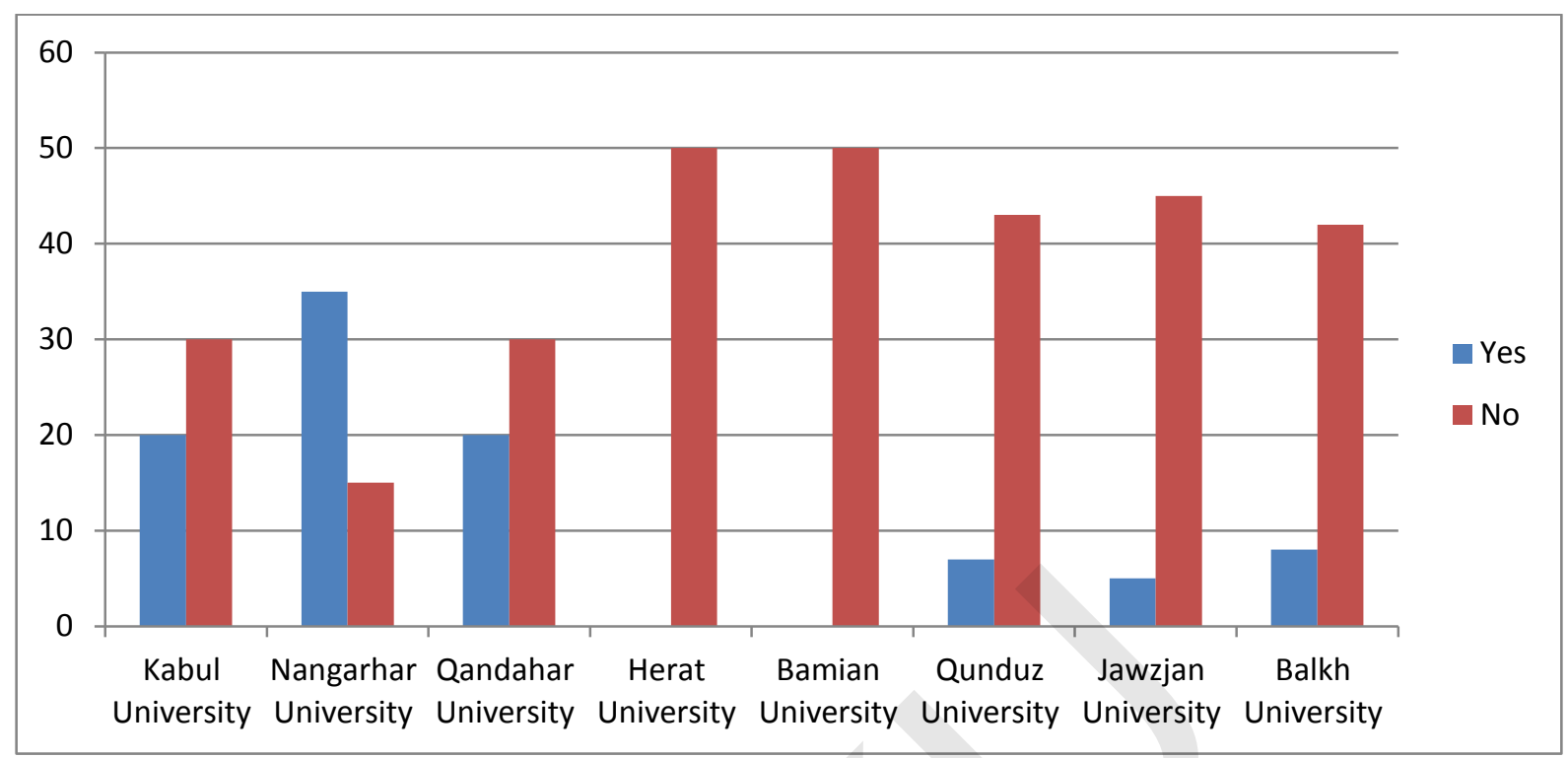

Figure 5 reflects the opinions of interviewees on whether the "armed opposition by the Taliban against the Afghan government is justified according to Islam?"

The sentiments of students largely mirrored those of staff. In Jalalabad students largely agree with the Taliban's strategy and objectives, however they disapprove of indiscriminate violence where there are civilian casualties and roads and homes destroyed. In Kabul, students who agreed with the Taliban strategy call for greater emphasis on religion in the government and claim that Taliban will bring greater legitimacy to governance in Afghanistan. On the other hand, students from Bamian, Herat, Qunduz, Jawzjan and Balkh University disagree with the Taliban and its strategy arguing that such violence is un-Islamic.

When asked about their views on the political climate in Afghanistan, most lecturers agreed that democracy alone cannot govern Afghanistan; rather a system that incorporates principles of the Quran is vital to both gain the trust of the people and to enforce moral codes of justice. However, these same lecturers remain critical of the democracy practiced by the central government and find that it is corrupt and hypocritical.

On women's rights, most lecturers believe that women are an integral part of Afghan society and have the right to work, in government or otherwise, as long as they abide by the rules and regulations of Islam in the conduct of their work. However, lecturers from Kabul, Nangarhar, and Bamian University believe that women should not work and should remain outside the public eye. However, Bamian University remains the only campus that follows the religious studies curriculum syllabus prepared by the Ministry of Higher Education; an indication that class room lectures and the personal opinions of lecturers remain separate. However, although the inclusion of religious studies as a compulsory component of public university curriculum is 
not unique to Afghanistan nor is it particular to Islamic nations, without oversight in place radical opinions and content may disseminate across lecture halls unchecked.

Students from Herat University pointed out that where you have Sunni professors and Shia students you are bound to have tension and conflict while students from Kabul University argue that religious lecturers try to avoid such student on student tension through censorship, permitting only their voices to be heard. According to a number of students from Kabul University, under such conditions lecturers carry on unchallenged with their verbal abuse as they ignore your questions, ridicule your point of view, and discourage any sense of critical analysis of religious studies. At Bamian University, some students preferring not to argue with lecturers remain silent. At Kabul University, where students claim that the Sunni-dominant departments disproportionately favor Sunnis over Shiite, sectarian violence has manifested on a number of occasions.

When examining and comparing the extent of student radicalization on and across university campuses as a consequence of influences from within the university system we find that although the conservative nature of lecturers from Kabul, Qandahar, and Nangarhar in and of itself is not seen as strongly influential in the radicalization of students, their call for taking up arms in the defense of Islam is. It is obviously a difficult task to change the long held position and opinions of these senior lecturers, however allowing these same lecturers to continue developing course syllabus outside of the Ministry of Higher Education's guidelines runs the risk of diffusing their potentially radical ideology across campus. In Bamian, although we find similarly conservative views, lecturers pose relatively less threat of diffusing their ideology as they adhere to the Ministry of Higher Education's syllabus guidelines. Particularly sensitive is the sectarian difference that exists throughout most classrooms and the approach lecturers take toward dealing with such difference. Maintaining a 'strictly by the book' lecture format may help to reduce the potential for the university as an institution to influence the radicalization of its students.

\section{The Extent of External Influences on the Radicalization of Students}

Findings suggest that external parties take advantage of their access to universities and co-opt the mobilizing power of student protests as a means for advancing their interests. In particular these groups develop patron-client relations with students through the support and funding of student association and the promise of post-graduation prospects. In return students become their mouthpieces in protest. Often, these relations instigate division along ethnic or sectarian lines, which encourages aggression among students. Moreover, the campuses that exhibit a greater sense of radicalized protests reside in close proximity to historically highly politicized regions where political parties, warlords, and Madrasas govern in a relatively conservative manner. One such case was recorded in Jalalabad where the Dar-ul-Olume Madrasa reportedly was responsible for the mobilization of student protest against the US presence in Afghanistan (VOA, 
2013). Another was reported in Kabul, where Jamiat-e-Islah mobilized student protest against the proposed Law for the Elimination of Violence Against Women (EVAW) (Osman, 2013a).

Employing both technical ${ }^{6}$ and direct means, Jamiat-e-Islah reportedly encouraged more than three hundred students to stand in protest against the proposed legislation. Considered a charity organization (Habibi, 2013) and a social reform movement (Hashmi, 2012) that closely resembles the ideology of the Muslim Brotherhood (Larson, 2009), Jamiat-e-Islah argues for a stronger Islamic government. Although it has its origins in the 1980s, it only recently officially registered in 2003 with the Ministry of Justice. Although it has a presence throughout Afghanistan, Jamiat-e-Islah has significant membership in Kabul and Nangarhar. Reportedly, membership is a long and arduous process and includes weekly classes under the supervision of other members for years. Nevertheless, anyone can participate in their protest activities. Such was the case in 2013 when they protested against the ouster of Egyptian President Muhammad Morsi (Osman, 2013) at Kabul University and in a number of other areas. Some of their key divisive arguments include a call for the elimination of women from the public sphere and their return to traditional roles, and the rejection of what are seen as Western-inspired human rights and values in favor of traditional Islamic values rooted in Salafism.

In addition to recruiting students, reportedly these groups seek out a more permanent presence on campus. In recent years a number of student associations have been established across university campuses in Afghanistan. Lecturers in Balkh University view the establishment of religious associations and otherwise as a democratic right and a positive step toward increased freedom of expression on campus. However, they also fear the potential for the dissemination of radical views by the external parties who establish and/or fund these student associations. As the Ministry of Higher Education does not provide financial support for student associations, universities are forced to look elsewhere. As a consequence, external parties dictate the lines along which student associations are established. In Herat and Kabul, lecturers claim that student associations are established along ethnic lines, while in Jawzjan, reportedly student associations are backed by warlords. As many of these groups act as gatekeepers to postgraduation opportunities, students are forced to develop patron-client relations as a means of securing their future and as a result may have to adopt their radical ideology in the process.

${ }^{6}$ Groups such as Jamiat-e-Islah employ a number of tools for recruiting and transmitting their propaganda such as social media, workshops and seminars, and direct means. The use of social media and the Internet as a means of mobilization has grown exponentially over the last decade. For example, in the first six months of a web presence Jamiat-e-Islah recorded over 720,000 visitors and nearly 47,000 Facebook likes. 


\section{CONCLUSION}

This study aimed to examine the trends in student radicalization across eight university campuses in Afghanistan. We conclude that student radicalization is more evident on campuses located in Kabul, Qandahar, and Nangarhar, however the university as an institution does not play a strong role in the radicalization of its students. Rather, a charged political climate and the readily available opportunity to mobilize quickly enable students to stand in protest rather easily. However, findings also suggest that it is this same easy access to mobilize in protest that seems to attract a number of external groups as evident by the black, white and green flags representative of al-Qaeda, the Taliban, and the militant wing of Hezb-e-Islami Hekmatyar. Moreover, it is these protests that seem to encourage polarization and consequential division on campus which increasingly resemble the practice of takfir. Left unchecked, the division it encourages may spread beyond university campuses and to the larger society as post-graduation unemployment is on the rise leaving students with time on their hands to take to the streets in protest.

\section{POLICY IMPLICATIONS}

According to (USAID, 2014), the United States alone has spent over \$19 billion in development assistance, including in the education sector, since 2001. In 2014, it was estimated that over 10 million students, including more than 2.5 million girls, benefited from such aid and are now enrolled in school. This is up from the 2002 estimates of 900,000 boys with almost no girls attending. While such figures are encouraging and reflect positively on US and international intervention in Afghanistan, it is vital that such programs continue to receive the oversight necessary to ensure that such aid is not in vain and that progress is not reversed. The potential for the manipulation of such projects is very real while the cost to ensure against such manipulation is minimal relative to that already spent.

Although our findings suggest that the university does not play a strong role in the radicalization of its students, the Ministry of Education can take steps to further insulate students against the potential for radicalization of students in the future. While the police option remains on the table as a means of countering violent protest, a soft approach may prove a better option in the long run, especially since many students protest against the use of force by the state and international forces. Such soft approach should include civil society coalition or watchdog organization to monitor higher education practices, standards, and quality of instruction. They should especially watch for external interference in the development of curriculum and the implementation of practices and standards that may promote radical ideology. In addition to safeguarding investments already made in country, such actions may discourage and limit infiltration of radical ideology. 
Another option includes the funding and implementation of more diversified student associations to complement the predominantly religious-based groups that already exists. In addition to providing a greater range of extracurricular activities for students, such non-religious based programs is expected to encourage intergroup participation that look beyond ethnic and sectarian differences as membership should not make such distinctions. As a result, not only can such programs discourage radicalized ideology founded on ethnic and sectarian differences and division, they may also actively encourage greater cohesion among students and communities.

As students are largely most concerned about post-graduation follow-on careers, The Ministry of Higher Education should institutionalize job placement, internship, and fellowship programs for students and prospective graduates based on merit with particular emphasis on eliminating favoritism and nepotism. University programs should continue to develop their place in students' lives. Especially important is the development of student confidence in the university as a trusted partner, one that does not discriminate based on ethnic or sectarian differences in the process of supporting students throughout their studies and follow-on career.

Success in limiting and insulating students against radicalization rests in instituting such standards across all university campuses and within all faculties. Moreover, the Ministry of Education should provide continuing education for staff and lecturers aimed at promoting and maintaining such standards. Failing to apply such measures inevitably faces the potential of degrading gains made and consequently squandering all the funds and effort already put forward. As the scope of this study is limited to the last decade, further studies are recommended to track trends and changes over time. Follow-on studies should aim to investigate the extent to which external groups gain access to student mobilization and influence the development of curriculum and teaching practices. 


\section{ANNEXES}

\section{Annex 1: Questionnaire Thematic and Structure}

Questions are based on the following themes organized according to research target groups.

The research target groups

1. Students as the primary source

2. Religious studies lecturers and university imams

3. General studies and social science lecturers

4. Student union representatives and managers of university dormitories

\section{Students}

1. Islamic values, religious activities on campus, and influence of religious political organizations

2. Institutional factors including policy of religious education and classroom environment

3. External factors including presence of international community, Afghan media, and Taliban

4. Views on human rights, democracy, gender and sectarian concerns

\section{Religious studies lecturers and university imams}

1. Development and changes to curriculum and mosque discourse

2. Trends in student interests, participation, and sentiments

3. Political change and its influence on religious studies

General and social science lecturers, hostel managers, and external experts

1. Structure and change in student views on the role of religion versus secular values

2. Sectarian makeup and dynamics of interaction at dormitory and student union

3. Structure relations between student union and external parties 


\section{Annex 2: References}

AbuKhalil, As' ad. "The Incoherence of Islamic Fundamentalism: Arab Islamic Thought at the End of the 20th Century." The Middle East Journal (1994): 677-94.

Ahmed, Azam. "Student Killed in Melee at Afghan University." The New York Times (2012). http://www.nytimes.com/2012/11/25/world/asia/student-killed-in-melee-at-afghanuniversity.html?_r=0\&pagewanted=print.

Altbach, Philip G, and Robert Cohen. "American Student Activism." Journal of Higher Education 61, no. 1 (1990): $32-49$.

Amstutz, J. Bruce. Afghanistan: The First Five Years of Soviet Occupation. Washington: National Defense University Press, 1986.

Arnold, Anthony. Afghanistan, the Soviet Invasion in Perspective. Hoover International Studies. Rev. and enl. ed. Stanford: Hoover Institution Press, 1985.

Ashour, Omar. The De-Radicalization of Jihadists: Transforming Armed Islamist Movements. Contemporary Terrorism Studies. London: Routledge, 2009.

Azzi, Assaad Elia, Xenia Chryssochooc, Bert Klandermans, Bernd Simon, and Jacquelien van Stekelenburg. Identity and Participation in Culturally Diverse Societies: A Multidisciplinary Perspective. Malden, MA: Wiley-Blackwell, 2011.

Coll, Steve. "Days of Rage." The New Yorker (2012).

Cookson, J. E. The Friends of Peace: Anti-War Liberalism in England, 1793-1815. Cambridge: Cambridge University Press, 1982.

Davis, Deborah, and Ezra F. Vogel. Chinese Society on the Eve of Tiananmen: The Impact of Reform. Harvard Contemporary China Series. Cambridge: Harvard University Press, 1990.

Diab, Khaled. "The Caliphate Fantasy." The New York Times, 2014.

Emadi, Hafizullah. "Radical Political Movements in Afghanistan and Their Politics of Peoples' Empowerment and Liberation." Central Asian Survey 20, no. 4 (2001): 427-50.

Fishbein, Michael. The History of Al-Tabari: The War between Brothers. Suny Series in near Eastern Studies. Albany: State University of New York Press, 1992.

Freeley, Austin J. Argumentation and Debate: Critical Thinking for Reasoned Decision Making. 13th ed. Boston: Wadsworth Cengage, 2013.

Frey, R. G., and Christopher W. Morris. Violence, Terrorism, and Justice. Cambridge Studies in Philosophy and Public Policy. Cambridge: Cambridge University Press, 1991.

Garfinkle, Adam M. Telltale Hearts: The Origins and Impact of the Vietnam Antiwar Movement. 1st ed. New York: St. Martin's Press, 1995.

Giustozzi, Antonio. "Between Patronage and Rebellion: Student Politics in Afghanistan." In Briefing Paper Series. Kabul, Afghanistan: Afghanistan Research and Evaluation Unit, 2010.

Goodson, Larry P. Afghanistan's Endless War: State Failure, Regional Politics, and the Rise of the Taliban. Seattle: University of Washington Press, 2001.

Gritzner, Jeffrey A., and John F. Shroder. Afghanistan. Modern World Nations. 2nd ed. New York: Chelsea House, 2007.

Habibi, Mujiburrahman. "Jamiat-E-Islah Provides Needy with Foodstuffs in Jalalabad." Wakht News Agency, 7/14/2013 2013.

Hashmi, Abdul Moeed. "6-Day Quran Learning Programme Ends." Pajhwok Afghan News, 4/6/2012 2012.

Hodge, Nathan, and Habib Khan Totakhil. "U.S. Funds Buy No Love at Afghan College." New York Times, http://online.wsj.com/article/SB10001424127887323998604578567823216827676.html?mod=wsj_streaming_stream.

Huldt, Bo, and Erland Jansson. The Tragedy of Afghanistan: The Social, Cultural, and Political Impact of the Soviet Invasion. London: Croom Helm, 1988.

Hussain, Irshaad. "The Hermeneutics of Takfir." Islam from Inside, http://islamfrominside.com/Pages/Articles/Hermeneutics\%20of\%20takfir.html.

Kakar, Javed Hamim. "Thousands of Afghan Students Protest against Us Forces." http://www.rawa.org/temp/runews/2009/12/09/thousands-of-afghan-students-protest-against-us-forces.html.

Kakar, M. Hassan. Afghanistan: The Soviet Invasion and the Afghan Response, 1979-1982. Berkeley: University of California Press, 1995.

Lapakko, David. Argumentation: Critical Thinking in Action. Bloomington: iUniverse, 2009.

Larson, Anna. "Toward an Afghan Democracy? Exploring Perceptions of Democratisaton in Afghanistan." Kabul: Afghanistan Reseach and Evaluation Unit, 2009. 
Mason, Herman Skip. Politics, Civil Rights, and Law in Black Atlanta. Black America. 1st ed. Charleston: Arcadia Publishing, 2000.

McCauley, Clark, and Sophia Moskalenko. "Mechanisms of Political Radicalization: Pathways toward Terrorism." Terrorism and Political Violence 20, no. 3 (2008/07/01 2008): 415-33.

McCormick, Anita Louise. The Vietnam Antiwar Movement in American History. In American History. Berkeley Heights: Enslow Publishers, 2000.

Mitchell, Gordon R. "Pedagogical Possibilities for Argumentative Agency in Academic Debate." Argumentation and Advocacy 35, no. 2 (1998): 41-60.

Moussalli, Ahmad. "Wahhabism, Salafism and Islamism: Who Is the Enemy?". Beirut: American University of Beirut, 2009.

Osman, Borhan. "The Evaw Law - an Evil Law? The Backlash at Kabul University." Kabul: Afghanistan Analyst Network, 2013.

"Under Strange Flags: Afghans' Delayed Protests against an 'Anti-Islam Film'." Kabul: Afghan Analyst Network, 2012.

Rubin, Barnett R. The Fragmentation of Afghanistan: State Formation and Collapse in the International System. 2nd ed. New Haven: Yale University Press, 2002.

Sampson, Edward E. "Student Activism and the Decade of Protest." Journal of Social Issues 23, no. 3 (1967): 1-33.

Sedgwick, Mark. "The Concept of Radicalization as a Source of Confusion." Terrorism and Political Violence 22, no. 4 (2010): 479-94.

Seferiades, Seraphim, and Hank Johnston. "The Dynamics of Violent Protest: Emotions, Repression and Disruptive Deficit." In Violent Protest, Contentious Politics, and the Neoliberal State, edited by Seraphim Seferiades and Hank Johnston. London: Ashgate, 2012.

Shafiq, M Najeeb, Jessica Mason, Taylor Seybolt, and Kristin DeLuca. "Are Student Protests in Arab States Caused by Economic and Political Grievances? Empirical Evidence from the 2006-07 Arab Barometer." Peabody Journal of Education 89, no. 1 (2014): 141-58.

Silber, Mitchell D, and Arvin Bhatt. Radicalization in the West: The Homegrown Threat. Police Department New York, 2007.

Southers, Erroll G. Homegrown Violent Extremism. Oxford: Anderson Publishing, 2013. text.

Springer, Devin R., James L. Regens, and David N. Edger. Islamic Radicalism and Global Jihad. Washington, D.C.: Georgetown University Press, 2009.

Sultani, Abbas Ali. "Kabul University: Students' Protest and Hunger Strike." http://www.outlookafghanistan.net/topics.php?post_id=7454.

Timani, Hussam S. Modern Intellectual Readings of the Kharijites. New York: Peter Lang, 2008.

USAid. "Frequently Asked Questions." Washington, DC: USAid, 2014.

VOA. "Afghanistan Students University Demonstration." VOA, http://www.darivoa.com/content/afghanistan-studentsuniversity-demonstration-131137018/1439727.html.

Wadsam. "Afghan Students Protest against Kankor Exam Results." Wadsam, http://www.wadsam.com/afghan-studentsprotest-against-kankor-exam-results-2321.

Walizada, Akram. "Afghan Students Protest against Civilian Casualties." Reuters, http://in.reuters.com/article/2009/05/10/idINIndia-39523920090510.

Wasserstrom, Jeffrey N. Student Protests in Twentieth-Century China: The View from Shanghai. Stanford: Stanford University Press, 1991.

Weiss, Meredith L., Edward Aspinall, and Mark R. Thompson. "Understanding Student Activism in Asia." In Student Activism in Asia: Between Protest and Powerlessness, edited by Meredith L. Weiss and Edward Aspinall. Minnesota: University of Minnesota Press, 2012.

White, Robert W. "From Peaceful Protest to Guerrilla War: Micromobilization of the Provisional Irish Republican Army." American Journal of Sociology (1989): 1277-302.

Wiktorowicz, Quintan. "A Genealogy of Radical Islam." Studies in Conflict \& Terrorism 28, no. 2 (2005): 75-97.

Islamic Activism: A Social Movement Theory Approach. Indiana Series in Middle East Studies. Bloomington: Indiana University Press, 2004.

Wright, Teresa. The Perils of Protest: State Repression and Student Activism in China and Taiwan. Honolulu: University of Hawai'i Press, 2001.

Xinhua. "Students Rally to Call for Foreign Forces Pull out from Afghanistan." Xinhua, http://english.peopledaily.com.cn/90777/7650661.html. 


\section{Annex 3: About the AISS}

The Afghan Institute for Strategic Studies (AISS) was established in October 2012 in Kabul. It aims to create an intellectual space for addressing strategic issues pertaining to Afghanistan in the wider regional and international contexts. Promoting dialogue between and among different stakeholders is an end as well an integral means in attaining AISS objectives. All AISS' activities and programs are based on the principles of professionalism, independence, internationalism and progressive values.

AISS is an independent research body, officially registered with the Afghan Ministry of Economy as a not-for-profit research institute dedicated to providing qualitative, non-partisan and policy-oriented research; publication; professional training and policy advocacy with a distinct focus on Afghanistan. Empowering and investing in Afghan youth constitutes the crosscutting priority of the AISS.

\section{Board of Advisors}

- Ambassador Hikmet Çetin (retd), former NATO Senior Representative to Afghanistan;

- Ambassador Kai Eide, former Special Representative to the UN Secretary General;

- Prof. Radha Kumar, Director General, Delhi Policy Group (DPG);

- Mr. Nader Nadery, Head of the Free and Fair Election Foundation of Afghanistan (FEFA);

- Dr. Barnett Rubin, Director and Senior Fellow, Center on International Cooperation, and Professor of Political Science at New York University;

- Dr. Sima Samar, Chairwoman, Afghanistan Independent Human Rights Commission (AIHRC);

- Dr. Rangin Spanta, Afghanistan's National Security Advisor;

- Dr. Ashley J. Tellis, Senior Associate, Carnegie Endowment for International Peace (CEIP); and

- Prof. Wang Jisi, President of the Institute of International and Strategic Studies (IISS) at Peking University. 
This Page Intentionally Left Blank 


\section{CONTACT}

Afghan Institute for Strategic Studies (AISS) |

Former Turquoise Mountain Fort | Post Box No: 5214 | Karte-Parwan | Kabul | Afghanistan

Abdul Ahad Mohammadi

Head, Department of Peace Studies

E: amohammadi@aiss.af

Robert Zaman

Visiting Fellow

E: rz37@kent.ac.uk

Musab Omer

Researcher, Department of Peace Studies

E:musab.omer@aiss.af

www.aiss.af | contact@aiss.af | Facebook: facebook.com/afghaninstituteforstrategicstudies |

Twitter: @aissofficialpag | LinkedIn: Afghan Institute for Strategic Studies

Commercial use of all publications by the AISS is not permitted without the written consent of the AISS.

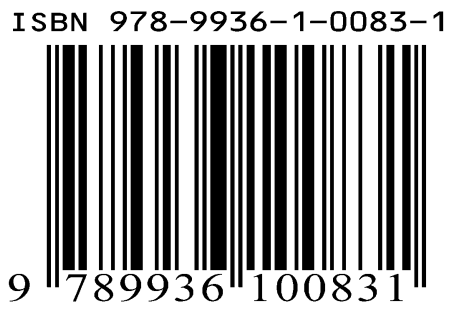

The analyses provided in this report are those of the research team and do not reflect the official position of Afghan Institute for Strategic Studies (AISS) or National Endowment for Democracy (NED) 